Duncan, D. C., and J. H. Devries. 2018. Agricultural destruction of Northern Pintail nests on cropland in prairie Canada. Avian Conservation and Ecology 13(2):6. https://doi.org/10.5751/ACE-01243-130206

Copyright (C) 2018 by the author(s). Published here under license by the Resilience Alliance.

Research Paper

\title{
Agricultural destruction of Northern Pintail nests on cropland in prairie Canada
}

\author{
David C. Duncan and James H. Devries ${ }^{1,2}$ \\ ${ }^{1}$ Ducks Unlimited Canada, ${ }^{2}$ Institute for Wetland and Waterfowl Research
}

\begin{abstract}
It has been postulated that the decline of the Northern Pintail (Anas acuta) population is related to the propensity of female pintails to nest in cropland. Using spatial modeling at multiple scales, we estimated that the long-term average (1961-2009) breeding population of Northern Pintails in prairie Canada would have initiated a mean of 974,260 nests/year, of which $47 \%$ ( $457,900+/-$ $43,270)$ would have been in cropland. Nest success rates are very low $(5 \%)$ in spring-seeded cropland with predation and agricultural activity responsible for approximately $78 \%$ and $22 \%$ of the nest loss, respectively. We estimated that a long-term mean of $94,750(+/-$ $19,680)$ nests representing 524,725 pintail eggs would have been destroyed by agricultural seeding and tillage operations on cropland annually. The number of nests/eggs lost in any given year would vary by an order of magnitude dependent primarily upon the size of the pintail population nesting on the prairies in that year. Our estimate of incidental take is quite robust because it is based on multiple, long-term studies using data from across the Canadian prairies. Our analysis provides additional support for the theory that the pintail's habit of nesting in cropland is the probable reason for the decline in the pintail population, irrespective of the cause of nest loss. Although predation is the primary cause of the loss of pintail nests in cropland, the proportion of nests lost to predation in cropland is similar to that in other upland habitats on the prairies. Thus the additional loss from agriculture could well be incremental and may be the proximate causative factor in the pintail population's decline and failure to recover in recent decades.
\end{abstract}

\section{Destruction de nids de Canard pilet causée par l'agriculture sur les terres cultivées des Prairies canadiennes}

RÉSUMÉ. Une des raisons avancées pour expliquer la diminution de la population de Canard pilet (Anas acuta) est en lien avec la propension des femelles à nicher sur les terres cultivées. Au moyen de modélisation spatiale à de multiples échelles, nous avons estimé que la population nicheuse moyenne de longue date (1961-2009) de Canard pilet des Prairies canadiennes aurait initié une moyenne de 974260 nids/année, dont $47 \%(457900$ +/- 43 270) se seraient trouvés sur les terres cultivées. Le taux de succès des nids est très faible $(5 \%)$ sur les terres à culture de printemps, où la prédation et les activités agricoles sont responsables de $78 \%$ et de $22 \%$ des pertes de nids, respectivement. Nous avons estimé qu'une moyenne de 94750 (+/-19 680) nids équivalant à 524725 oeufs de pilets auraient été détruits annuellement par les opérations de travail du sol et d'ensemencement sur les terres cultivées. Le nombre de nids/oeufs détruits au cours d'une année donnée variait d'abord en fonction de la taille de la population de pilets nichant dans les Prairies cette année-là. Notre estimation de la prise accessoire est assez fiable parce qu'elle est fondée sur de multiples recherches de longue date utilisant des données provenant des Prairies canadiennes. Notre analyse corrobore la théorie selon laquelle la diminution de la population de Canard pilet serait probablement attribuable à l'habitude de l'espèce de nicher sur les terres cultivées, peu importe la cause sousjacente à la perte de nids. Même si la prédation est la cause première de la perte des nids de pilets sur les terres cultivées, la proportion de nids détruits par la prédation sur les terres cultivées est similaire à celle observée dans d'autres milieux secs des Prairies. Ainsi, la perte additionnelle causée par les activités agricoles pourrait être incrémentielle et se révéler être le facteur causal direct de la diminution de la population de pilets et de l'échec de son rétablissement dans les récentes décennies.

Key Words: agriculture; Anas acuta; bird mortality; egg loss; incidental take; nest success; Northern Pintail

\section{INTRODUCTION}

Human-related activities result in the direct inadvertent killing of hundreds of millions of birds and eggs annually in Canada (Calvert et al. 2013). Calvert et al. (2013) found that most estimates of incidental take of birds in Canada were $<1 \%$ of the population, well below the $10 \%$ that they considered might cause a detectable population impact. There are very few instances where the current impacts of direct incidental human-related mortality are thought to result in population-level declines
(Arnold and Zink 2011, Calvert et al. 2013). Although Longcore and Smith (2013) cautioned against focusing only on species where such mortality might cause population declines, it is reasonable to do so because priority-setting exercises based on conservation concern are the norm in conservation biology (Mehlman et al. 2004, Beston et al. 2016). In this paper, we quantify the nonintentional anthropogenic mortality for one of the few avian species in North America where it has been proposed that direct human-caused mortality may be responsible for the population decline. 
Fig. 1. Estimated long-term average (1961-2009) breeding Northern Pintail (Anas acuta) pair density (pairs $/ \mathrm{km}^{2}$ ) as a function of wetland, upland, and geographic covariates in the Prairie Pothole Region (PPR; outlined in red) of Canada (Devries 2014).

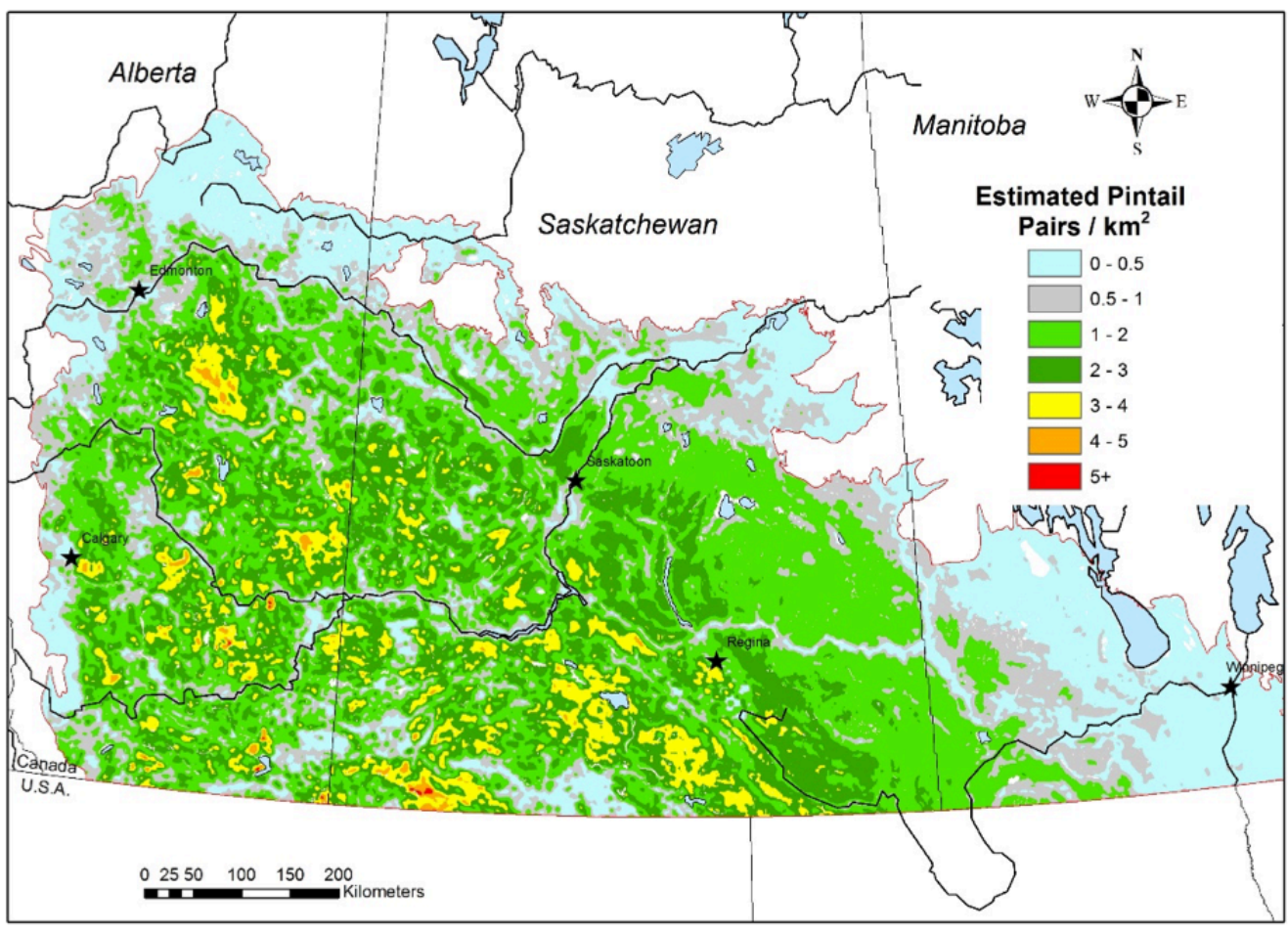

The North American population of the Northern Pintail (Anas acuta; hereafter pintail) has declined from about 10 million in the mid-1950s to approximately 3 million in recent years (USFWS 2016). Multiple lines of evidence indicate that the reason for this decline is related to reduced productivity as opposed to changes in survival rates (Hestbeck 1995, Miller and Duncan 1999, Herbert and Wassenaar 2005, Rice et al. 2010). Miller and Duncan (1999) postulated that the decline of the pintail population was a result of its unusual readiness to nest in cropland where very few nests survive (Goelitz 1918, Milonski 1958, Klett et al. 1988, Greenwood et al. 1995, Devries et al. 2018). Pintails in prairie Canada lay their largest clutches in April (Duncan 1987, Guyn and Clark 2000, Richkus 2002), and these early nests are vulnerable to subsequent spring seeding operations. With approximately $70-75 \%$ of the Canadian prairies now cultivated (Gauthier and Wiken 2003) and pintails nesting in cropland roughly in proportion to its availability on the landscape (Richkus 2002, Devries 2014, Devries et al. 2018), cropland appears to be sink habitat for pintails (Miller and Duncan 1999, Podruzny et al. 2002, Devries et al. 2018). Early estimates of nest destruction in cropland indicated that agricultural activity caused $34-56 \%$ of the nest losses (Milonksi 1958, Higgins 1977). Although Miller and Duncan (1999) considered loss to agricultural activities to be an important source of pintail nest destruction in cropland, a number of more recent studies have suggested that predation is the predominant cause of duck nest loss in cropland (Richkus 2002, Devries et al. 2008a, Devries 2014, Skone et al. 2015, Devries et al. 2018). Although a number of studies have documented the habitat nesting preferences of pintails (Klett et al. 1988,
Greenwood et al. 1995, Devries et al. 2018), we are unaware of any estimate of numbers of nests initiated in cropland and impacted by incidental take from agriculture.

In this study, we quantify the exposure of pintail nests in cropland to loss from accidental anthropogenic destruction (incidental take) versus predation on their primary breeding grounds in prairie Canada. We use field data, geospatial models of pintail distribution, and nest habitat selection models to estimate the proportion and number of pintails that nest on cultivated land in prairie Canada, and then calculate the number and proportion of pintail nests and eggs destroyed by cultivation versus predation. Our multimodel approach represents a unique and powerful method to estimate potential impacts of anthropogenic disturbance on demographic processes while accounting for geographic variation in population and habitat distribution across large spatial scales, an approach at the nexus of conservation and ecology (Beissinger et al. 2006).

\section{METHODS}

We took a four-part modeling approach to estimating exposure of pintail nests to agricultural disturbance in prairie Canada. First, we used a species distribution model (SDM) developed by one of us (JHD) for pintails in the Prairie Pothole Region (PPR) of Canada and the U.S. (Devries 2014; Fig. 1). The pintail SDM was developed using pintail count data from 809 systematically located permanent survey transect segments as part of the May Breeding Waterfowl Population and Habitat Survey (MBWPHS) conducted annually by the U.S. Fish and Wildlife Service and the 
Fig. 2. Network of $41-\mathrm{km}^{2}$ grids $(\mathrm{n}=13,285)$ used in ArcGIS to extract estimated Northern Pintail (Anas acuta) breeding pairs, and habitat availability, for input into a productivity model that estimated the number of pintail nests initiated in spring-seeded cropland.

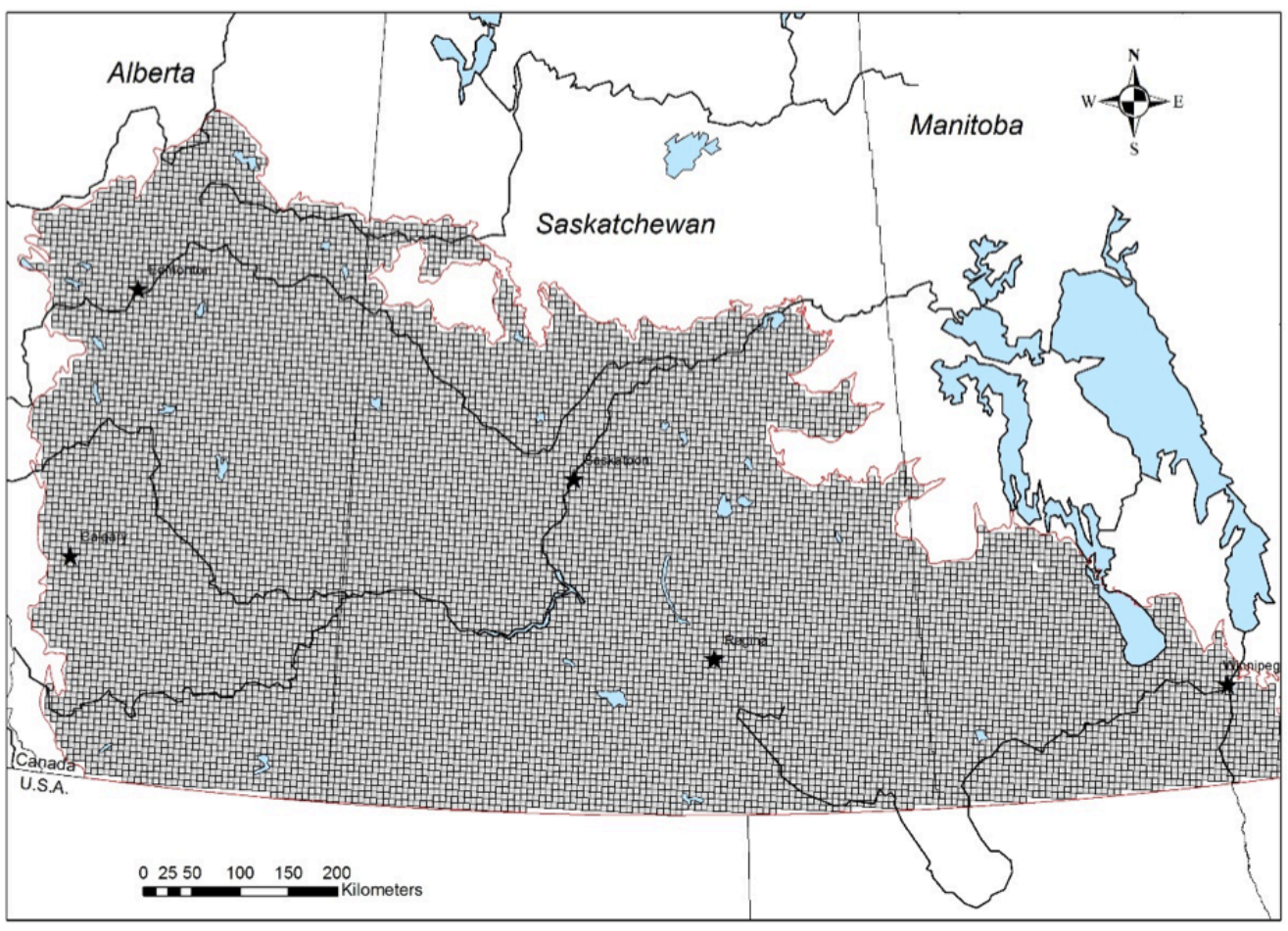

Canadian Wildlife Service (Benning 1976). Long-term average breeding pair estimates (1961-2009) were modeled as a function of various GIS-based habitat covariates associated with each survey segment using negative binomial regression. The SDM pair density layer for the PPR was then created by applying the best fitting model to continuous covariate values extracted in ArcGIS. From this layer, we extracted the estimated breeding pairs in each of $13,28541-\mathrm{km}^{2}$ grid cells covering the Canadian portion of the PPR (Fig. 2).

Second, for each grid cell, we determined contemporary habitat composition for each of eight habitat classes (spring-seeded cropland, fall-seeded cropland, idle grassland, grazed grassland, hayland, wetland, trees/shrubs, and other) using Agriculture and Agri-Food Canada's (AAFC) 2014 annual crop mapping digital layer (http://open.canada.ca/data/en/dataset/ba2645d5-4458-414db196-6303ac06c1c9). Because wetlands are poorly captured in AAFC's crop mapping layer, we recalculated habitat composition after including estimated wetland habitat area from Ducks Unlimited Canada's (DUC) adjusted CanVec hydrology layer (Natural Resources Canada 2011). DUC CanVec adjustments are based on a spatial model contrasting CanVec versus DUC wetland inventory data (i.e., digitized wetlands at a scale of 1:5000 or better; imagery resolution $0.5 \mathrm{~m}-2.5 \mathrm{~m}$, DUC unpublished data). The DUC adjusted wetland layer has previously been used to estimate waterfowl distribution across the Canadian and U.S. portion of the PPR (Doherty et al. 2015).

Third, we used a deterministic model of pintail productivity (hereafter, productivity model), based on pintail nest habitat selection and habitat-specific nest survival estimates, to calculate potential exposure of pintail nests to incidental take in croplands. These estimates were developed from multiple nesting studies conducted across 62 study sites in prairie Canada (1997-2009) and included nest attributes and fate of 1005 pintail nests found with equal nest searching effort across habitats (Devries et al. 2018). Nest habitat selection was estimated using resource selection functions comparing the distribution of used versus random locations among habitats at the scale of the $41-\mathrm{km}^{2}$ study areas (Devries et al. 2018). The productivity model generally follows the structure of a similar model developed for the Mallard (Anas platyrhynchos; Johnson et al. 1987). In each grid cell (above), the productivity model was used to generate a population of nests from the estimated breeding pairs based on duck nesting, renesting propensity, and nesting effort estimates from the published literature as follows. Because nesting propensity has not been estimated for prairie-breeding pintails, we used the average nesting propensity $(0.90)$ for a large sample of radiomarked female Mallards studied in the Canadian PPR (Devries et al. 2008b). We set declining renest probabilities of $0.85,0.5$, and 0.2 for early, mid, and late-season based on seasonally declining renest probabilities observed for Mallards (Arnold et al. 2010, Devries 2014). The model allowed a maximum of three nest attempts per season based on pintail renesting behavior reported by Grand and Flint (1996) and Guyn and Clark (2000). Nests were distributed into available habitats based on temporally (within season) and spatially varying (habitat availability) habitat selection algorithms (Devries et al. 2018). 
Table 1. Summary of statistics for habitat availability (productivity model input) and proportion of Northern Pintail (Anas acuta) nests in each habitat (productivity model output) across $41-\mathrm{km}^{2}$ grid cells $(\mathrm{n}=13,285)$ covering the Canadian portion of the Prairie Pothole Region.

\begin{tabular}{|c|c|c|c|c|c|c|c|c|c|}
\hline \multirow[b]{2}{*}{$\begin{array}{l}\text { Model Input / } \\
\text { Output }\end{array}$} & \multirow[b]{2}{*}{ Statistics } & \multicolumn{8}{|c|}{ Nest Habitat $^{\dagger}$} \\
\hline & & $\begin{array}{c}\text { Spring-seeded } \\
\text { Cropland }\end{array}$ & $\begin{array}{c}\text { Fall-seeded } \\
\text { Cropland }\end{array}$ & Idle Grass & $\begin{array}{c}\text { Grass } \\
\text { Pasture }\end{array}$ & Hayland & Wetland & $\begin{array}{c}\text { Trees/ } \\
\text { shrubs } \\
\end{array}$ & Other \\
\hline \multirow[t]{5}{*}{ Habitat Availability } & Mean & 0.499 & 0.007 & 0.027 & 0.215 & 0.082 & 0.049 & 0.103 & 0.017 \\
\hline & Std.Dev. & 0.297 & 0.011 & 0.084 & 0.190 & 0.078 & 0.093 & 0.172 & 0.048 \\
\hline & Median & 0.541 & 0.003 & 0.008 & 0.161 & 0.057 & 0.020 & 0.029 & 0.007 \\
\hline & Min & 0.000 & 0.000 & 0.000 & 0.000 & 0.000 & 0.000 & 0.000 & 0.000 \\
\hline & $\operatorname{Max}$ & 0.997 & 0.169 & 1.000 & 0.880 & 0.445 & 0.997 & 0.985 & 0.994 \\
\hline Proportion of & Mean & 0.468 & 0.011 & 0.040 & 0.274 & 0.118 & 0.089 & 0.000 & 0.000 \\
\hline \multirow[t]{4}{*}{ Nests in Habitat } & Std.Dev. & 0.261 & 0.018 & 0.095 & 0.213 & 0.092 & 0.160 & 0.000 & 0.000 \\
\hline & Median & 0.494 & 0.004 & 0.022 & 0.223 & 0.100 & 0.034 & 0.000 & 0.000 \\
\hline & Min & 0.000 & 0.000 & 0.000 & 0.000 & 0.000 & 0.000 & 0.000 & 0.000 \\
\hline & $\operatorname{Max}$ & 0.994 & 0.219 & 1.000 & 0.910 & 0.399 & 1.000 & 0.000 & 0.000 \\
\hline
\end{tabular}

${ }^{\dagger}$ The pintail productivity model includes "Trees/shrubs" and "Other" as available habitat, however, no nests are distributed in these habitats because nest site selection estimates are 0 .

Finally, we reviewed information from the literature on nest survival rates and causes of nest loss, and used best estimates combined with the modeled estimates of the number of nests in croplands and clutch size to estimate the mean number of nests/ eggs lost to agricultural activities and predation. We restricted our analysis to pintails nesting on the Canadian prairies because this is where a majority of pintails nest and much of our ancillary data was derived from this region (e.g., Greenwood et al. 1995, Miller and Duncan 1999, Devries et al. 2018). We estimated variation in the annual number of nests destroyed by agricultural machinery using the Delta method (Oehlert 1992) to combine estimated variances in the following: (1) the number of nests initiated in spring-seeded cropland; (2) the nest survival rate in spring-seeded cropland; and (3) the proportion of nests lost to agricultural machinery reported in the literature. Unless otherwise indicated, we present estimates $\pm 1 \mathrm{SE}$.

\section{RESULTS}

We estimated that an average of 731,160 pintail pairs settled to breed in prairie Canada between 1961 and 2009, and that these birds initiated a mean of 974,260 nests. Based on contemporary habitat availability inputs for prairie Canada, and long-term average pintail population distribution, the productivity model estimated approximately $47 \%$ of pintail nests would be initiated in spring-seeded cropland, $27 \%$ in grassland pasture, $12 \%$ in haylands, and $9 \%$ in wetlands (Table 1). Thus our model-based estimate of the number of pintail nests initiated in spring-seeded cropland is 457,900 nests/year. We assumed nest numbers vary directly with the pintail population size in prairie Canada and therefore used the coefficient of variation in the annual breeding population estimates from prairie Canada (Waterfowl Breeding and Habitat Survey, Benning 1976) and applied it to our estimate of nests in spring-seeded cropland to develop the standard error $(\mathrm{SE}= \pm 43,270$; Table 2).

To determine the number of nests and eggs destroyed in cropland, we first reviewed waterfowl nest survival estimates in cropland. Nest survival of ducks in spring-seeded cropland is low compared to most other habitat types (Klett et al. 1988, Greenwood et al.
1995), ranging from $<1-4 \%$ (Richkus 2002), $\%$ (Greenwood et al. 1995), and 7\% (Klett et al. 1988). Devries et al. (2008a) reported a relatively high nest success rate of $12 \%$ in spring-seeded cropland and opined that this may have been a result of their inclusion of late-season nests because success rates in spring-seeded cropland can increase substantially throughout the growing season (Emery et al. 2005). Recently, one of us (JHD) modeled mean pintail nest success in spring-seeded cropland to be $5.1 \%$ (i.e., daily survival rate $=0.9111 \pm 0.0146$; Table 2 ) based on the fate of 153 nests in cropland (Devries et al. 2018). Thus for estimates herein, we used a nest loss rate of $95 \%$ in spring-seeded cropland, which produced an estimate of 435,000 pintail nests destroyed annually in cropland.

To estimate the loss caused by the incidental take from agricultural operations, we reviewed causes of duck nest loss in cropland. Early studies (Milonksi 1958, Higgins 1977) reported that agricultural activities such as seeding and tillage were responsible for the loss of $34-56 \%$ of duck nests on cultivated land. However, these studies had small sample sizes, were localized in geographic coverage, were not conducted in prairie Canada, and occurred at a time when farming practices would have differed from those of today. More contemporary studies from prairie Canada have found that predation is the predominant cause of duck nest loss in cropland rather than farming operations. Greenwood et al. (1995) and Devries et al. (2008a) reported that $17 \%$ and $\cong 22 \%$, respectively, of nests of various duck species in cropland (primarily spring-seeded) in prairie Canada were lost to agricultural activity. Pintail nest loss from agricultural practices in spring-seeded cropland estimated from various sources averages $21.8 \%( \pm 1.3 \%$; Table 2$)$. In all studies reviewed, predation caused the loss of the remainder of the nests that were not abandoned. These more contemporary studies consistently demonstrate that agricultural activities are not the primary cause of pintail nest loss in cropland. Given the above mean and variance estimates for the number of pintails nesting in cropland, cropland nest survival and proportion of nests destroyed by farm machinery, we estimate 94,750 ( $\pm 19,680$; based on Delta method) pintail nests were destroyed annually by agricultural operations 
Table 2. Parameter estimates and standard errors used in the calculation of Northern Pintail (Anas acuta) eggs lost to destruction by agricultural machinery annually in spring-seeded cropland in prairie Canada.

\begin{tabular}{|c|c|c|c|}
\hline Parameter & Source & Estimate (SE) & Details \\
\hline $\begin{array}{l}\text { Pintail nests initiated in } \\
\text { spring-seeded cropland }\end{array}$ & Model-based & $457,900(43,270)$ & $\begin{array}{l}\text { SE based on coefficient of variation in prairie } \\
\text { Canada pintail population estimates }{ }^{\dagger}, 1961-2015\end{array}$ \\
\hline $\begin{array}{l}\text { Pintail daily nest survival } \\
\text { rate (DSR) in spring-seeded } \\
\text { cropland }\end{array}$ & Devries et al. 2018 & $0.911(0.01465)$ & $\begin{array}{l}\mathrm{n}=153 \text { pintail nests in cropland; nest survival rate }= \\
5.1 \% \text { (i.e., } \mathrm{DSR}^{32} \text { ) }\end{array}$ \\
\hline $\begin{array}{l}\text { Proportion of pintail nests } \\
\text { in spring-seeded cropland } \\
\text { lost to machinery }\end{array}$ & $\begin{array}{l}\text { Greenwood et al. } 1995 \\
\text { Devries et al. } 2008 a \\
\text { Devries } 2014 \\
\text { Klett et al. } 1988\end{array}$ & $\begin{array}{c}0.1830 \\
0.2140 \\
0.2360 \\
0.2390 \\
0.2180(0.0129)^{\S}\end{array}$ & $\begin{array}{l}17 \text { of } 97 \text { pintail nest losses (Table } 11^{\ddagger} \text { ) } \\
6 \text { of } 28 \text { pintail nest losses } \\
26 \text { of } 110 \text { pintail nest losses } \\
22 \text { of } 92 \text { pintail nest losses (Table } 5^{\ddagger} \text { ) }\end{array}$ \\
\hline Clutch size & $\begin{array}{l}\text { Ducks Unlimited Canada, } \\
\text { unpublished data }\end{array}$ & $7.8(0.122)$ & $\begin{array}{l}\mathrm{n}=145 \text { pintail nests in cropland with full clutch } \\
\text { known }\end{array}$ \\
\hline \multicolumn{4}{|c|}{$\begin{array}{l}{ }^{\dagger} \text { Benning (1976) } \\
\text { Table reference in cited publication } \\
{ }^{\$} \text { Mean (SE) of listed estimates }\end{array}$} \\
\hline
\end{tabular}

in prairie Canada, with the remainder lost to predation. We extended this estimate to the number of eggs lost given approximately $42 \%$ of nests are lost with a full clutch of 7.8 eggs (Table 2; DUC, unpublished data) and we assumed the remainder were lost with half that number during laying, yielding approximately 524,725 eggs destroyed annually.

\section{DISCUSSION}

Many estimates of anthropogenic-related bird mortality use extrapolations from small-scale studies, which were not designed to be scaled up and often are based on limited data (Calvert et al. 2013, Machtans and Thogmartin 2014). Calvert et al. (2013) considered most recent Canadian estimates of incidental take to be accurate only within an order of magnitude. Our estimates of the proportion and number of pintail nests destroyed in cropland overcome these shortcomings because they are derived from large datasets from multiple, geographically broad, long-term studies in prairie Canada. Furthermore, our modeling approach allowed us to not only account for the average distribution of the pintail population within prairie Canada (and hence its exposure to available cropland/grassland at the prairie-wide scale) but also for nest-site selection from among the available habitats at a local scale. These advantages, combined with the similarity of our overall proportion of pintails nesting in cropland to that of other studies (see below), lead us to a high degree of confidence in the robustness of our estimates, unlike many other estimates of incidental take. In addition, we have incorporated well documented sources of variance in our estimates that wholly or partially account for the following: (1) total continental pintail population size, which has been declining over time (USFWS 2016); (2) number of pintails settling on the prairies, which is partly related to annual wetland conditions (Hestbeck 1995, Miller and Duncan 1999); (3) settling distribution of pintails within the prairies relative to variances in land use and habitat availability (Devries et al. 2018); (4) annual variation in nest success (Greenwood et al. 1995, Guyn and Clark 2000); and (5) renesting persistence (Duncan 1987, Guyn and Clark 2000).
Although the absolute number of pintail nests in cropland can fluctuate greatly among years, the $47 \%$ proportion of pintail nests estimated in cropland is considerably less variable because of the relative stability in the regional amount of cropland over time (Devries et al. 2018) and the minimal influence of varying population size on habitat selection. Greenwood et al. (1995) estimated that $45 \%$ and $34 \%$ of pintail nests were in cropland on the Canadian prairies and parklands, respectively, using less sophisticated methodology. Because many more pintails nest in the prairies as compared to the parkland (Miller and Duncan 1999), Greenwood et al.'s (1995) 45\% figure would be more representative of the pintail population. Richkus (2002) estimated that $51 \%$ of pintails in southern Saskatchewan nested in cropland, although his study was conducted in a much more localized area. Thus our overall estimate of $47 \%$ of the pintail nests in the Canadian prairies being initiated in spring-seeded cropland is consistent with other sources, despite differences in years and methodologies.

From a conservation perspective, the large proportion of pintails nesting in cropland is more important than a given number of nests destroyed in cropland in any particular year. Low duck nest success in cropland compared to native grassland is well established (Klett et al. 1988, Greenwood et al. 1995, Devries et al. 2018) and the negative impact of conversion of native grassland to cropland on duck populations over time has been demonstrated at various scales (Bethke and Nudds 1995, Podruzny et al. 2002, Drever et al. 2007). Pintails have been particularly impacted by cultivation and their decline has been attributed to the conversion of grassland to cropland (Miller and Duncan 1999, Podruzny et al. 2002). Our findings herein that almost half of the pintail nests in prairie Canada occur in cropland where they suffer a very low nest success rate provides additional support for the hypothesis that the pintail's proclivity to nest in cropland is the cause of its decline.

We cannot definitively say that the additional pintail nests lost to incidental take by agriculture is the cause of the decline in the 
pintail population, however the evidence is suggestive and our estimates are near the $10 \%$ range suggested by Calvert et al. (2013) as potential for population level impact (after fledging rates are considered). Although predation rather than agriculture causes the bulk of pintail nest loss on cropland, predation generally causes $70-80 \%$ loss of duck nests on the prairies in virtually all upland habitat types (Klett et al. 1988, Greenwood et al. 1995). Pintails are unique in that (i) they are the only prairie duck species that has exhibited a long-term decline and failed to respond positively to high pond numbers over the past decade, and (ii) they have a large proportion of their population nesting in cropland where nest success is lower than most other habitat types. The fact that duck nest success is relatively high, e.g., $>20 \%$, in fall-seeded crops (Cowan 1982, Duebbert and Kantrud 1987, Devries et al. 2008a, Skone et al. 2015) and higher than in most other habitat types (Klett et al. 1988, Greenwood et al. 1995), suggests that in the absence of spring tillage, nest success on seeded cropland can be quite high. Although the high nest success in fallseeded cropland is confounded by its taller vegetative cover earlier in the summer compared to spring-seeded crops, the evidence is suggestive that the loss from agricultural activities may indeed be additive and responsible for the decline in the pintail population. It should also be recognized that the general habitat category of cropland includes land that is fallowed, a practice that has greatly decreased over time. This change in agricultural practice on cropland may have significantly influenced pintail nesting and success (Podruzny et al. 2002), although that study did not include the very high pintail populations of the mid-late 1950s in its analysis.

There have been very few studies of birds nesting in cropland in prairie Canada, most likely because there are few bird species that nest in cropland in relatively high densities (e.g., Owens and Myres 1973, DeJong et al. 2004), and there are many logistical challenges to conducting nest searches on actively farmed lands (Devries et al. 2008a). A few other prairie-nesting bird species that readily nest in cropland are Horned Larks (Eremophila alpestris), longspurs (Owens and Myre 1973, McMaster and Davis 2001, Martin and Forsyth 2003,), Killdeers (Charadrius vociferus; Higgins 1975), Long-billed Curlew (Numenius americanus; Devries et al. 2010), and Marbled Godwit (Limosa fedoa; Garvey et al. 2013). Because of the prevalence of cropland on the prairies, a substantial proportion of the population of these species could nest in cropland. Tews et al. (2013) modeled the potential effect of agriculture on Horned Larks and estimated that the loss of Horned Larks from farming operations was low, however their estimates were coarse and subject to high uncertainty, e.g., their two estimates of the size of the prairie-breeding Horned Lark population varied by an order of magnitude. We encourage others to pursue studies of bird species that are prone to nest in cropland to more accurately determine the potential impact of tillage and cultivation on those species.

\section{CONCLUSION}

Almost half of the pintail nests on the Canadian prairies are initiated in cropland, a habitat in which nest loss is extremely high and greater than in most other habitat types. Predators are responsible for three-quarters of the nest loss on cropland with agricultural activities being responsible for the remainder. A number of those nests that are destroyed by agricultural activities would undoubtedly be lost to predation even in the absence of human-caused destruction. Although it remains to be determined whether the additive effect of agricultural activity causes sufficient incremental loss as to be the cause of the persistently low pintail population size, the high nest success observed in fall-seeded crops (Cowan 1982, Duebbert and Kantrud 1987, Devries et al. 2008a, Skone et al. 2015) suggests that nest success in annual crops can be quite high in the absence of spring seeding and tillage. Our finding of a high proportion of pintail nests in cropland, combined with the relatively low nest success rate, provide additional support for the hypothesis that cropland nesting is the causative factor behind the pintail population's decline, irrespective of the cause of nest loss. We encourage further investigation of this question using tools like integrated population models (Arnold et al. 2018). In the absence of any readily acceptable method of reducing mechanical destruction of duck nests during spring seeding or tillage operations, fall-seeded crops like winter wheat or fall rye and/or conversion of annual cropland to perennial crops appear to offer the best solutions to improve pintail nest success rates on the prairies.

Responses to this article can be read online at: http://www.ace-eco.org/issues/responses.php/1243

\section{Acknowledgments:}

We are grateful to Environment and Climate Change Canada for funding of the analyses and manuscript preparation, and to Ducks Unlimited Canada for use of their modeling systems. We thank $L$. Armstrong for her assistance with the statistical analyses, and J. Ingram, B. Bartzen, and two anonymous reviewers for their helpful comments on the manuscript.

\section{LITERATURE CITED}

Arnold, T. W., R. G. Clark, D. N. Koons, and M. Schaub. 2018. Integrated population models facilitate ecological understanding and improved management decisions. Journal of Wildlife Management 82:266-274. http://dx.doi.org/10.1002/jwmg.21404

Arnold, T. W., J. H. Devries, and D. W. Howerter. 2010. Factors that affect renesting in Mallards (Anas platyrhynchos). Auk 127:212-221. http://dx.doi.org/10.1525/auk.2009.09028

Arnold, T. W., and R. M. Zink. 2011. Collision mortality has no discernible effect on population trends of North American birds. $P L O S$ ONE 6(9):e24708. http://dx.doi.org/10.1371/journal. pone. 0024708

Beissinger, S. R., J. R. Walters, D. G. Catanzaro, K. G. Smith, J. B. Dunning, Jr., S. M. Haig, B. R. Noon, and B. M. Smith. 2006. Modeling approaches in avian conservation and the role of field biologists. Ornithological Monographs 59:1-56. http://dx.doi. org/10.2307/40166820 http://dx.doi.org/10.2307/40166820

Benning, D. S. 1976. Standard procedures for waterfowl population and habitat surveys: operating manual. U.S. Fish and Wildlife Service, Office of Migratory Bird Management, Laurel, Maryland, USA. 
Beston, J. A., J. E. Diffendorfer, S. R. Loss, and D. H. Johnson. 2016. Prioritizing avian species for their risk of population-level consequences from wind energy development. PLOS ONE 11(3): e0150813. http://dx.doi.org/10.1371/journal.pone.0150813

Bethke, R. W., and T. D. Nudds. 1995. Effects of climate change and land use on duck abundance in Canadian prairie-parklands. Ecological Applications 5:588-600. http://dx.doi.org/10.2307/1941969

Calvert, A. M., C. A. Bishop, R. D. Elliot, E. A. Krebs, T. M. Kydd, C. S. Machtans, and G. J. Robertson. 2013. A synthesis of human-related avian mortality in Canada. Avian Conservation and Ecology 8(2):11. http://dx.doi.org/10.5751/ACE-00581-080211

Cowan, W. F. 1982. Waterfowl production on zero tillage farms. Wildlife Society Bulletin 10(4):305-308.

DeJong, J. R., D. E. Naugle, K. K. Bakker, F. R. Quamen, and K. F. Higgins. 2004. Impacts of agricultural tillage on grassland birds in western South Dakota. Pages 76-80 in D. Egan and J. A. Harrington, editors. Proceedings of the 19th North American Prairie Conference: the Conservation Legacy Lives On. University of Wisconsin-Madison, Madison, Wisconsin, USA.

Devries, J. H. 2014. Fitness consequences of avian habitat selection in dynamic landscapes: multi-scale evaluations in northern pintails. Dissertation, University of Saskatchewan, Saskatoon, Saskatchewan, Canada.

Devries, J. H., L. M. Armstrong, R. J. MacFarlane, L. Moats, and P. T. Thoroughgood. 2008a. Waterfowl nesting in fall-seeded and spring-seeded cropland in Saskatchewan. Journal of Wildlife Management 72:1790-1797. http://dx.doi.org/10.2193/2007-513

Devries, J. H., R. W. Brook, D. W. Howerter, and M. G. Anderson. $2008 b$. Effects of spring body condition and age on reproduction in Mallards (Anas platyrhynchos). Auk 125:618-628. http://dx.doi. org/10.1525/auk.2008.07055

Devries, J. H., R. G. Clark, and L. M. Armstrong. 2018. Dynamics of habitat selection in birds: adaptive response to nest predation depends on multiple factors. Oecologia 187(1):305-318. http://dx. doi.org/10.1007/s00442-018-4134-2

Devries, J. H., S. O. Rimer, and E. M. Walsh. 2010. Cropland nesting by Long-billed Curlews in southern Alberta. Prairie Naturalist 42:123-129.

Doherty, K. E., J. S. Evans, J. Walker, J. H. Devries, and D. W. Howerter. 2015. Building the foundation for international conservation planning for breeding ducks across the U.S. and Canadian border. PLOS ONE 10(2):e0116735. http://dx.doi. org/10.1371/journal.pone.0116735

Drever, M. C., T. D. Nudds, and R. G. Clark. 2007. Agricultural policy and nest success of prairie ducks in Canada and the United States. Avian Conservation and Ecology 2(2):5. http://dx.doi. org/10.5751/ACE-00175-020205

Duebbert, H. F., and H. A. Kantrud. 1987. Use of no-till winter wheat by nesting ducks in North Dakota. Journal of Soil and Water Conservation 42:50-53.

Duncan, D. C. 1987. Nesting of Northern Pintails in Alberta: laying date, clutch size, and renesting. Canadian Journal of Zoology 65:234-246. http://dx.doi.org/10.1139/z87-038
Emery, R. B., D. W. Howerter, L. M. Armstrong, M. G. Anderson, J. H. Devries, and B. L. Joynt. 2005. Seasonal variation in waterfowl nesting success and its relation to cover management in the Canadian prairies. Journal of Wildlife Management 69 (3):1181-1193. http://dx.doi.org/10.2193/0022-541X(2005)069[1181: SVIWNS]2.0.CO;2

Garvey, M. E., E. Nol, D. W. Howerter, and L. M. Armstrong. 2013. A spatial analysis of factors affecting nest success of shorebirds in the Canadian prairies. Condor 115(1):58-66. http:// dx.doi.org/10.1525/cond.2012.110146

Gauthier, D. A., and E. B. Wiken. 2003. Monitoring the conservation of grassland habitats, prairie ecotone, Canada. Environmental Monitoring and Assessment 88(1-3):343-364. http://dx.doi.org/10.1023/A:1025585527169

Goelitz, W. A. 1918. The destruction of nests by farming operations in Saskatchewan. Auk 35:238-240. http://dx.doi. org/10.2307/4072879

Grand, J. B., and P. L. Flint. 1996. Renesting ecology of Northern Pintails on the Yukon-Kuskokwim Delta, Alaska. Condor 98:820-824. http://dx.doi.org/10.2307/1369862

Greenwood, R. J., A. B. Sargeant, D. H. Johnson, L. M. Cowardin, and T. L. Shaffer. 1995. Factors associated with duck nest success in the prairie pothole region of Canada. Wildlife Monographs 128:3-57.

Guyn, K. L., and R. G. Clark. 2000. Nesting effort of Northern Pintails in Alberta. Condor 102:619-628. http://dx.doi. org/10.2307/1369793

Hebert, C. E., and L. I. Wassenaar. 2005. Stable isotopes provide evidence for poor Northern Pintail production on the Canadian prairies. Journal of Wildlife Management 69(1):101-109. http://dx. doi.org/10.2193/0022-541X(2005)069<0101:SIPEFP>2.0.CO;2

Hestbeck, J. B. 1995. Response of Northern Pintail breeding populations to drought, 1961-92. Journal of Wildlife Management 59(1):9-15. http://dx.doi.org/10.2307/3809109

Higgins, K. F. 1975. Shorebird and game bird nests in North Dakota croplands. Wildlife Society Bulletin 3(4):176-179.

Higgins, K. F. 1977. Duck nesting in intensively farmed areas of North Dakota. Journal of Wildlife Management 41(2):232-242. http://dx.doi.org/10.2307/3800600

Johnson, D. H., D. W. Sparling, and L. M. Cowardin. 1987. A model of the productivity of the Mallard duck. Ecological Modelling 38(3-4):257-275. http://dx.doi.org/10.1016/0304-3800 (87)90100-1

Klett, A. T., T. L. Shaffer, and D. H. Johnson. 1988. Duck nest success in the prairie pothole region. Journal of Wildlife Management 52:431-440. http://dx.doi.org/10.2307/3801586

Longcore, T., and P. A. Smith. 2013. On avian mortality associated with human activities. Avian Conservation and Ecology 8(2):1. http://dx.doi.org/10.5751/ACE-00606-080201

Machtans, C. S., and W. E. Thogmartin. 2014. Understanding the value of imperfect science from national estimates of bird mortality from window collisions. Condor 116(1):3-7. http://dx. doi.org/10.1650/CONDOR-13-134.1 
Martin, P. A., and D. J. Forsyth. 2003. Occurrence and productivity of songbirds in prairie farmland under conventional versus minimum tillage regimes. Agriculture, Ecosystems, and Environment 96:107-117. http://dx.doi.org/10.1016/S0167-8809 (02)00234-7

McMaster, D. G., and S. K. Davis. 2001. An evaluation of Canada's permanent cover program: habitat for grassland birds? Journal of Field Ornithology 72(2):195-210. http://dx.doi. org/10.1648/0273-8570-72.2.195

Mehlman, D. W., K. V. Rosenberg, J. V. Wells, and B. Robertson. 2004. A comparison of North American avian conservation priority ranking systems. Biological Conservation 120:383-390. http://dx.doi.org/10.1016/j.biocon.2004.03.013

Miller, M. H., and D. C. Duncan. 1999. The Northern Pintail in North America: status and conservation needs of a struggling population. Wildlife Society Bulletin 27(3):788-800.

Milonski, M. 1958. The significance of farmland for waterfowl nesting and techniques for reducing losses due to agricultural practices. Transactions of the North American Wildlife and Natural Resource Conference 23:215-227. Wildlife Management Institute, Washington, D.C., USA.

Natural Resources Canada. 2011. CanVec feature catalogue. Natural Resources Canada, Centre for Topographic Information, Sherbrooke, Québec, Canada.

Oehlert, G. W. 1992. A note on the delta method. American Statistician 46:27-29. http://dx.doi.org/10.1080/00031305.1992.10475842

Owens, R. A., and M. T. Myres. 1973. Effects of agriculture upon populations of native passerine birds of an Alberta fescue grassland. Canadian Journal of Zoology 51(7):697-713. http://dx. doi.org/10.1139/z73-104

Podruzny, K. M., J. H. Devries, L. M. Armstrong, and J. J. Rotella. 2002. Long-term response of Northern Pintails to changes in wetlands and agriculture in the Canadian Prairie Pothole Region. Journal of Wildlife Management 66:993-1010. http://dx.doi. org/10.2307/3802932

Rice, M. B., D. A. Haukos, J. A. Dubovsky, and M. C. Runge. 2010. Continental survival and recovery rates of Northern Pintails using band-recovery data. Journal of Wildlife Management 74(4):778-787. http://dx.doi.org/10.2193/2008-598

Richkus K. D. 2002. Northern Pintail nest site selection, nest success, resending ecology, and survival in the intensively farmed prairies of southern Saskatchewan: an evaluation of the ecological trap hypothesis. Dissertation. Louisiana State University. Baton Rouge, Louisiana, USA.

Skone, B. R., J. J. Rotella, and J. Walker. 2015. Waterfowl production from winter wheat fields in North and South Dakota. Journal of Wildlife Management 80(1):127-137. http://dx.doi. org/10.1002/jwmg.993
Tews, J., D. G. Bert, and P. Mineau. 2013. Estimated mortality of selected migratory bird species from mowing and other technical operations in Canadian agriculture. Avian Conservation and Ecology 8(2):8. http://dx.doi.org/10.5751/ACE-00559-080208

U.S. Fish and Wildlife Service. 2016. Waterfowl population status, 2016. U.S. Department of the Interior, Washington, D.C., USA. 